\title{
Evaluation of the Efficacy of Pulsed Electromagnetic Therapy in the Treatment of Back Pain: A Randomized Controlled Trial in a Tertiary Hospital in Nigeria
}

\author{
KI Oke ${ }^{1}$ PFA Umebese ${ }^{2}$
}

\begin{abstract}
Musculoskeletal system disorders (MSDs) are amongst the most commonly encountered problems in orthopaedics and physiotherapy practice all over the world and back pain is amongst the most prevalent of musculoskeletal presentations encountered in clinical practice. The attendant deformities, huge economic loss among many other sequelae on the affected individuals have always informed the search for cost-effective treatment modalities that are non-invasive and are devoid of, or at least have minimal side effects. This randomized controlled trial was conducted to assess the therapeutic efficacy of the use of a non-pharmacological device [pulsed electromagnetic field (PEMF)] modality in the treatment of back pain. A total of 16 patients (mean age: $42.82 \pm 8.63$ years) with back pain without radiculopathy who met the inclusion criteria were purposively enrolled in the study. Patients were randomly assigned into two groups. Group A had eight patients treated with PEMF plus medications (analgesics, nonsteroidal anti-inflammatory - diclofenac sodium) while the eight patients in group $B$ were treated with only standard medications. The PEMF device was applied in group A four times a day for the period the patients were admitted (maximum of nine days). Measured outcome parameters were reduction in pain as assessed with numeric pain rating scale (NPRS) and improvement in functional ability status as assessed with functional activity scale (FAS). Obtained data were analysed with paired and independent $t$-test to test the significant efficacy of the treatment outcomes in the two groups. There was a statistically significant faster pain relief and resumption of active functions in patients treated with PEMF plus analgesic compared with the rates exhibited by patients treated with standard analgesics alone. These results suggest that PEMF therapy is beneficial in reducing pain and disability in patients with back pain and should be made part of holistic care for back pain. Further studies using PEMF on larger patient populations are advocated to further confirm the efficacy of PEMF therapy in back pain management.
\end{abstract}

Keywords: Efficacy, electromagnetic therapy, back pain

\section{Evaluación de la Eficacia de la Terapia Electromagnética en Pulsos en el Tratamiento de Lumbago: Prueba Controlada Aleatoria en un Hospital Terciario de Nigeria \\ KI Oke ${ }^{1}$, PFA Umebese ${ }^{2}$}

\begin{abstract}
RESUMEN
Los trastornos del sistema músculo-esquelético (SME) se encuentran entre los problemas más comunes en la práctica de la ortopedia y la fisioterapia en todo el mundo, en tanto que el lumbago se halla entre las manifestaciones más prevalecientes en la práctica clínica. Las deformidades concomitantes y las enormes pérdidas económicas - entre otras muchas secuelas que afectan a los individuos en estos casos - han sido siempre razón para buscar modalidades de tratamientos costo-efectivos, que no sean invasivos y estén totalmente libres de efectos secundarios, o tengan al menos efectos colaterales mínimos. Esta prueba controlada aleatoria se realizó para evaluar la eficacia terapéutica de una modalidad no farmacológica [terapia con campos electromagnéticos (PEMF)] en el tratamiento del
\end{abstract}

From: ${ }^{1}$ Department of Physiotherapy and ${ }^{2}$ Department of Orthopaedics and Traumatology, University of Benin Teaching Hospital, Benin City, Edo State, Nigeria.
Correspondence: Dr KI Oke, Department of Physiotherapy, University of Benin Teaching Hospital, PMB 1111, Benin City, Nigeria. E-mail: kayodeoke2001@yahoo.com 
lumbago. Un total de 16 pacientes (edad promedio: $42.82 \pm 8.63$ años) con lumbago sin radiculopatía, quienes satisfacian los criterios de inclusión criterios, fueron deliberadamente enrolados en este estudio. Los pacientes fueron aleatoriamente divididos en dos grupos. El grupo A estuvo formado por ocho pacientes tratados con PEMF además de medicamentos (analgésicos, antiinflamatorios no esteroideos, diclofenaco de sodio), mientras que los otros ocho pacientes en el grupo B fueron tratados sólo con medicamentos normales. El dispositivo PEMF se aplicó al grupo A dos veces al día durante el periodo de que los pacientes estuvieron ingresados (como máximo nueve días). Los parámetros medidos en relación con el resultado fueron la reducción de dolor evaluada de acuerdo con la escala de calificación del dolor (ECD) y la mejoría de la capacidad funcional, según la evaluación de la escala de la actividad funcional (EAF). Los datos obtenidos se analizaron con prueba t pareada y prueba de tindependiente a fin de comprobar la eficacia de los resultados del tratamiento en los dos grupos. En los pacientes tratados con PEMF y analgésicos, hubo tanto un alivio del dolor como una reanudación de las funciones activas significativamente más rápidos según las estadísticas, en comparación con los índices provenientes de los pacientes tratados con analgésicos normales solamente. Estos resultados sugieren que la terapia PEMF es beneficiosa para reducir el dolor y la discapacidad en los pacientes con lumbago, y debe hacerse parte de la atención holística al lumbago. Se recomienda realizar más estudios usando PEMF en poblaciones mayores de pacientes para confirmar aún más la eficacia de la terapia PEMF en el tratamiento de lumbago.

Palabras clave: Lumbago, eficacia, terapia electromagnética

West Indian Med J 2013; 62 (3): 206

\section{INTRODUCTION}

Pain is an important or predominant symptom of many illnesses. An acute pain is most often caused by an acute injury or pathological state, and lasts only as long as the tissue lesion itself persists (1). Worldwide, there is an epidemic of chronic disability resulting from simple sprains and strains and despite the best efforts, the problem is getting worse (2). Back pain affects an estimated $80 \%$ of the American population. It is second only to the common cold as a reason for outpatient visits and represents the single most common and most expensive industrial and occupational health problem (3). Back pain is a universal human condition with no evidence that the prevalence is higher in the United States of America (USA) than in the United Kingdom, with people having had back pain throughout recorded history (2).

Epidemiological reports indicate that musculoskeletal pain is a major medical and economic problem, and the pain associated disability is linked with a significant loss of productivity and substantial healthcare expenditures for women (4). It has been reported that about $30 \%$ of all sick-leave days in Sweden are due to neck/shoulder or low back pain (4). Back pain affects both men and women; the gender affectation ratio is controversial and the predisposing factors for musculoskeletal pain, and back pain specifically, differ between the two genders. Men are believed to report more work disability from low back pain (4).

Pain in the back is the commonest symptom encountered in orthopaedic practice (5). Various intervention strategies have been developed for back pain, and many studies have examined their success (6). It has been suggested that treatment at the sub-acute stage is the most effective $(7,8)$.
Effective treatment for sub-acute back pain will prevent the transition to chronic back pain (6). It is termed chronic when it lasts more than three months (9) but frequent episodes are described as recurrent back pain (10).

After three months of low back pain, only 5\% to $10 \%$ of patients have persistent symptoms, yet it is this population that accounts for $85 \%$ of the costs in terms of compensation and loss of work related to low back pain (3). Persistence or recurrence of low back pain and pain-related attitudes are associated with changes in motor strategy, providing a physiological link between psychological factors and low back pain recurrence (11).

Pain and movement difficulties are central to the practice of physical therapy. Historically, physical therapists have always played a major role in the management of patients with pain in primary, secondary and tertiary healthcare levels (1).

The action of pulsed electromagnetic field (PEMF) is based on creating small electrical fields in tissues and thereby promoting biological effects (12). Experimental observations have documented a significant impact of PEMF on a number of biological processes (13). It has also been used in the treatment of non-fracture musculoskeletal conditions (14, 15) such as low back pain. Pulse electromagnetic field has been demonstrated to enhance fibroblast, chondrocyte and osteoblast metabolism, as well as to modulate the effects of hormones and neurotransmitters on the receptors of different cell types. Beneficial effects following PEMF treatment have been claimed in a whole array of different conditions. More specifically, PEMF has been used for the treatment of avascular necrosis of the hips, Legg-Perthes' disease, osteo- 
porosis, tendinitis, chronic pain due to musculoskeletal disorders and delayed bone fractures (13). Effects of PEMF therapy have been studied and documented as positive in the treatment of conditions like fibromyalgia and osteoarthritis of the knee and cervical spine (16-18). Its effective impact on other conditions such as persistent rotator cuff tendinitis, interbody lumbar fusion and in patients undergoing arthroscopic reconstruction of the anterior cruciate ligament has also been studied and demonstrated (19-21). To the best of the authors' knowledge, the clinical use and therapeutic effectiveness of this non-invasive physical therapy modality in the care of back pain (acute and sub-acute) has not been adequately studied, at least in this part of the world, despite the disabling effects of back pain. This study therefore aims at filling this existing gap in knowledge and research efforts in Nigeria.

\section{SUBJECTS AND METHODS}

Sixteen patients (nine males and seven females) whose ages ranged from 25-54 years (mean $\pm \mathrm{SD}=26.00 \pm 8.62$ ), admitted in the orthopaedic wards of the University of Benin Teaching Hospital, Nigeria, were purposively selected for this study. They comprised two groups of eight patients who presented with acute to sub-acute mid and low (thoracolumbar spine) back pain associated with inability to carry out their basic and instrumental functional activities.

A total of 19 patients were initially enrolled in this study; however, three who did not meet the inclusion criteria were excluded from the study. The patients were all seen, assessed and diagnosed with acute and sub-acute back pain of thoracic and lumbar segments. Inclusion criteria were clinically verified painful mid or low back pain with reduced functional ability due to pain in the affected patients. Exclusion criteria were fracture/dislocations in the bones of the spine, prolapsed intervertebral discs, systemic neurological diseases, epilepsy, pregnancy and non-use of contraception in women of child-bearing age, pacemakers or any implanted electrical device. Group A which comprised five (5) males and three (3) females was treated with non-steroidal antiinflammatory medication (diclofenac) and electromagnetic field therapy device while group B which comprised four (4) males and females each received analgesics (diclofenac) medication only. The PEMF device (EMpulse (Model 301), EM-Probe Technologies, USA) was inserted into the painful area four times a day with the patient lying supine for a duration of two hours. The EMpulse device, which essentially emits a pulsed electromagnetic energy from a diode, was applied on the painful sites of the patients. Both groups were instructed on strict compliance with abstinence from additional pharmacological pain-relieving medication during the study period. Patients in the two groups also had soft tissue manipulation/massage with topical analgesic gel (diclofenac) and a regimen of muscle strengthening exercises. All the patients gave informed consent to participate in the study. Ethical approval was sought and received from the research and ethics committee of the hospital. The study lasted a period of fifteen months. Each patient, irrespective of the group, had a minimum of five days and a maximum of nine days treatment sessions.

Outcome measures assessed in the patients were pain at rest and on movement and functional ability status using standardized and validated scales of Numeric Pain Rating Scale (NPRS) and a modified version of Functional Activity Scale (FAS). The NPRS is designed to measure the patient's current level of pain compared with initial pain on entering therapy. One end of the NPRS represents intolerable (worst pain imaginable) pain level (denoted by a value of 10) and the other represents the pain-free state (denoted by a value of 0 ). The FAS is rated from A which refers to full functional ability to $\mathrm{C}$ which refers to inability to function at all. This study modified the rating values or words of $\mathrm{A}, \mathrm{B}$ and $\mathrm{C}$ of FAS with the use of 1, 2 and 3, respectively for the ease of use in statistical analysis. These parameters were assessed, measured and documented at admission and after treatment before discharge.

Thereafter, the measured variables, pre- and posttreatment, were fed into SPSS version 16 and analysed using the descriptive statistics of mean and standard deviation as well as the paired and independent $t$-test statistical methods to test the significance of difference in the two groups' outcome measures.

Independent $t$-test was used to determine the significance of the differences between the outcomes of pain severity (NPRS), functional activity scores (FAS) and days spent on admission (DSOA) pre- and post-treatment between the two groups. The same statistical package was also used to determine the significance of the difference between the ages of the subjects in the two groups. Paired (two-tailed) $t$ test was used to determine the significance of difference between pre- treatment pain severity between the two groups. Mean and standard deviation of the measured parameters were also analysed. Significance level was set at 0.05 .

\section{RESULTS}

The NPRS scores of groups A and B before treatment were mean $\pm \mathrm{SD}=8.00 \pm 1.06$ and mean $\pm \mathrm{SD}=8.00 \pm 1.07$, respectively. The mean and standard deviation NPRS scores of the two groups post-treatment were $1.38 \pm 1.51$ and $1.63 \pm$ 0.74 respectively. The mean and standard deviations of functional activity scores of groups A and B pre-treatment were $2.62 \pm 0.52$ and $2.75 \pm 0.46$ while the post-treatment values were $1.00 \pm 0.00$ and $1.25 \pm 0.46$. The number of days spent on admission by patients in group A ranged from 4-8 days (mean $\pm \mathrm{SD}=5.00 \pm 1.31$ ) while that of group $\mathrm{B}$ ranged from 2-9 days (mean $\pm \mathrm{SD}=7.00 \pm 2.27$ ) [Table 1]

The results of the independent $t$-test statistics showed no significant difference between the two groups in the pain rating scores of pre $(\mathrm{t}=3.718, p<0.002)$ and post treatments $(\mathrm{t}=17.00, p<0.000)$ [Table 2]. However, the independent $t$ test statistics showed a significant difference in the post- 
Table 1: Ages and pre- and post-treatment measured outcomes of the variables of the subjects in the two groups

\begin{tabular}{|c|c|c|c|c|}
\hline Variables & Group A & $($ mean \pm SD $)$ & Group B & $($ mean \pm SD $)$ \\
\hline Age (years) & $43.50 \pm 8.26$ & $42.13 \pm 8.99$ & & \\
\hline \multicolumn{5}{|l|}{ VAS } \\
\hline Pre-Rx & & $8.00 \pm 1.06$ & & $8.00 \pm 1.07$ \\
\hline Post-Rx & & $1.38 \pm 1.51$ & & $1.63 \pm 0.74$ \\
\hline \multicolumn{5}{|l|}{ FAS } \\
\hline Pre-Rx & & $2.62 \pm 0.52$ & & $2.75 \pm 0.46$ \\
\hline Post-Rx & & $1.00 \pm 0.00$ & & $1.25 \pm 0.46$ \\
\hline DSOA & $5.00 \pm 1.31$ & & $7.00 \pm 2.27$ & \\
\hline NOSRx & $8.25 \pm 1.83$ & Range $=5-10$ & & \\
\hline
\end{tabular}

$\mathrm{SD}=$ standard deviation; VAS = visual analogue scale; Pre-Rx $=$ pretreatment; Post-Rx = post-treatment; FAS = functional activity scale; DSOA $=$ day spent on admission; NOSRx $=$ number of sessions of treatment

Table 2: Paired $t$-test values of the groups' pre- and post-treatment values of the outcome measures

\begin{tabular}{lrc}
\hline Variables & t-value & $\boldsymbol{p}$-value \\
\hline VASgpA $\times$ VASgpB Pre-Rx & 3.718 & 0.002 \\
VASgpB $\times$ VASgpB Post-Rx & 17.000 & 0.000 \\
\hline
\end{tabular}

VAS $=$ visual analogue scale; $\mathrm{gpA} / \mathrm{gpB}=$ group $\mathrm{A} / \mathrm{B} ;$ Pre-Rx $=$ pretreatment; Post-Rx = post-treatment

treatment pain rating scores $(\mathrm{t}=0.42, p>0.061)$ and functional activity score $(\mathrm{t}=-1.528, p>0.000)$ of groups $\mathrm{A}$ and B. Meanwhile, the independent $t$-test statistics showed no significant difference in the ages of the subjects in the two groups ( $\mathrm{t}=0.318, p<0.842)$ and also in the number of days spent on admission $(\mathrm{t}=-2.160, p<0.285)$ by the subjects in the two groups (Table 3 ).

Table 3: Independent $t$-test values of the groups' age and pre- and posttreatment values of the outcome measures

\begin{tabular}{lcc}
\hline Variables & t- value & $\boldsymbol{p}$-value \\
\hline Age gpA $\times$ Age gpB & 0.318 & 0.842 \\
VASgpA $\times$ VASgpB Post-Rx & 0.421 & 0.061 \\
FASgpA $\times$ FASgpB Pre-Rx & -0.509 & 0.334 \\
FASgpA $\times$ FASgpB Post-Rx & -1.528 & 0.000 \\
DSOAgpA $\times$ DSOAgpB & -2.160 & 0.285 \\
\hline
\end{tabular}

VAS = visual analogue scale; gpA $/ g p B=$ group $\mathrm{A} / \mathrm{B} ;$ Pre-Rx $=$ pretreatment; Post-Rx = post-treatment; FAS = functional activity scale; DSOA $=$ day spent on admission

\section{DISCUSSION}

The results of this study have revealed that PEMF therapy combined with drug is more effective than using drugs alone in treating back pain. It has also showed that resumption of functional activity from the effects of back pain can occur earlier if back pain patients are treated with PEMF combined with analgesics than if treated with analgesic alone. Pulsed electromagnetic field has been used in treating various mus- culoskeletal injuries like ankle and shoulder joint injuries, hand injuries, cervical spondylosis and knee joint osteoarthritis, in different studies (22-25) with different reports of efficacy. The present study has revealed a significant improvement in the pain level and functional activity scores of the patients treated with PEMF combined with analgesics.

A randomized, double-blind, placebo-controlled study (26) has demonstrated significant reduction in pain and disability in patients with chronic low back pain treated with pulsed electromagnetic therapy three times a week for four weeks. This outcome is similar to the report of a study (25) which assessed the effect of PEMF on pain, range of motion (ROM) and functional status in patients with cervical osteoarthritis in a randomized, double-blind study and reported that pain levels and scores on disability scales in the PEMF group decreased significantly after therapy as compared to no change observed in the placebo group. The authors concluded that PEMF treatment offers a potential therapeutic adjunct to the existing cervical osteoarthritis therapies in the future. Pulsed magnetic fields (PEMF) have also been reported to have a considerable and statistically significant potential for reducing pain in cases of lumbar radiculopathy and whiplash syndrome when compared with constant waves (27). Magnetic fields therapy has also been revealed to have a considerable and statistically significant potential for reducing pain in cases of lumbar radiculopathy and the whiplash syndrome when compared with standard medication in the treatment of these conditions (27). Reports from researchers have revealed that patients with cervical spine pain treated with PEMF showed significant improvement in pain level on passive motion, joint tenderness and activities of daily living from baseline through mid-way and end of treatment to one month follow-up when compared with those who had placebo treatment $(18,28)$. The authors also concluded that PEMF has therapeutic benefit in painful cervical spine $(18,28)$. Although the present study showed no significant difference in the average number of days the subjects in both groups spent on admission for treatment, the difference in the number of days spent on admission by the patients treated with PEMF with medications and those with medications alone is different on descriptive statistics. Patients in the PEMF plus medication group resumed painless functional activity earlier than the patients in the medications only group. This observation of difference in the number of days before resumption of painless walking activities was also recorded in the study on patients with lumbar radiculopathy (27) treated with magnetic field therapy. Many investigators have examined the effects of PEMF on pain relief in chronic osteoarthritis of the knee joint and reported varying degrees of positive effects of PEMF on this condition $(13,29)$.

In conclusion, the present study has revealed a statistically significant effect in terms of reduction of pain and functional disability in patients with back pain when treated with PEMF in combination with conventional treatment. Considering the sample size in the study, generalization of 
the results may need to be done with caution; it is therefore suggested that further studies using this therapeutic device on larger patient populations and using the therapy alone are needed to further buttress or refute the efficacy of PEMF therapy in this condition.

\section{REFERENCES}

1. Forth W, Martin E, Peter K. The relief of pain: an analytical view of the advantages and disadvantages of modern pain management. Munich: Hoechst; 1986.

2. Waddell G. Low back pain: a twentieth century health care enigma. Spine (Phila Pa 1976) 1996; 21: 2820-5.

3. Hertling D, Kessler RM. Management of common musculoskeletal disorders: Physical therapy principles and methods. $2^{\text {nd }}$ ed. Philadelphia: Lippincott Williams and Wilkins; 1990.

4. Lautenbacher S. Sex-related differences in clinical and experimental muscle pain: In: Graven-Nielsen T, Arendt-Nielsen L, Mense S, eds. Fundamentals of musculoskeletal pain. $1^{\text {st }}$ ed. Seattle: IASP Press; 2008.

5. Adams JC, Hamblen DL. Outline of orthopaedics. $11^{\text {th }}$ ed. Edinburgh: Churchill Livingstone; 1990.

6. European Agency for Safety and Health at Work. Work-related musculoskeletal disorders: back to work report. Luxembourg: Office for Official Publications of the European Communities; 2007.

7. Waddell G, Burton AK. Occupational health guidelines for the management of low back pain at work: evidence review. Occup Med 2001; 51: 124-35.

8. Pengel LH, Herbert RD, Maher CG, Refshauge KM. Acute low back: systematic review of its prognosis. BMJ 2003: 327: 323.

9. Woolf $\mathrm{AD}$, Pfleger B. Burden of major musculoskeletal conditions. Bull World Health Organ 2003: 81: 646-56.

10. Frymoyer JW. Back pain and sciatica. New Engl J Med 1998: 319: 291-300.

11. Hodges PW. Sensory- motor changes in low back pain: In: GravenNielsen T, Arendt-Nielsen L, Mense S, eds. Fundamentals of musculoskeletal pain. $1^{\text {st }}$ ed. Seattle: IASP Press; 2008.

12. Thamsborg G, Florescu A, Oturai P, Fallentin E, Tritsaris K, Dissing S. Treatment of knee osteoarthritis with pulsed electromagnetic fields: a randomized, double-blind, placebo controlled study. Osteoarthritis Cartilage 2005; 13: 575-81.

13. Pipitone N, Scott DL. Magnetic pulse treatment for knee osteoarthritis: a randomised, double-blind, placebo-controlled study. Curr Med Res Opin 2001: 17: 190-6.

14. Bassett AL, Schink-Ascani M, Lewis SM. Effects of pulsed electromagnetic fields on Steinberg ratings of femoral head osteonecrosis. Clin Orthop 1989; 246: 172-85.

15. Aaron RK, Lennox D, Bunce GE, Ebert T. The conservative treatment of osteonecrosis of the femoral head: a comparison of core decompression and pulsing electromagnetic fields. Clin Orthop 1989; 249: 209-18.
16. Sutbeyaz ST, Sezer N, Koseoglu F, Kibar S. Low-frequency pulsed electromagnetic field therapy in fibromyalgia: a randomized, doubleblind, sham-controlled clinical study. Clin J Pain 2009; 25: 722-8.

17. Nicolakis P, Kollmitzer J, Crevenna R, Bittner C, Erdogmus CB, Nicolakis J. Pulsed magnetic field therapy for osteoarthritis of the knee - a double-blind sham-controlled trial. Wien Klin Wochenschr 2002; 30: $678-84$

18. Trock DH, Bollet AJ, Markoll R. The effect of pulsed electromagnetic fields in the treatment of osteoarthritis of the knee and cervical spine. Report of randomized, double blind, placebo controlled trials. J Rheumatol 1994; 21: 1903-11.

19. Binder A, Parr G, Hazleman B, Fitton-Jackson S. Pulsed electromagnetic field therapy of persistent rotator cuff tendinitis: a doubleblind controlled assessment. Lancet 1984; 31: 695-8.

20. Mooney V. A randomized double-blind prospective study of the efficacy of pulsed electromagnetic fields for interbody lumbar fusions. Spine (Phila Pa 1976) 1990; 15: 708-12.

21. Zorzi C, Dall'Oca C, Cadossi R, Setti S. Effects of pulsed electromagnetic fields on patients' recovery after arthroscopic surgery: prospective, randomized and double-blind study. Knee Surg Sports Traumatol Arthrosc 2007; 15: 830-4.

22. Wilson DH. Comparison of short-wave diathermy and pulsed electromagnetic energy in treatment of soft tissue injuries. Physiotherapy 1974; 60: 309-10.

23. Barclay V, Collier RJ, Jones A. Treatment of various hand injuries by pulsed electromagnetic energy (Diapulse). Physiotherapy 1983; 69: $186-8$.

24. Pennington GM, Danley DL, Sumko MH. Pulsed, non-thermal highfrequency electromagnetic energy (Diapulse) in the treatment of grade $\mathrm{i}$ and grade II ankle sprains. Mil Med 1993; 158: 101-4.

25. Sutbeyaz ST, Sezer N, Koseoglu BF. The effect of pulsed electromagnetic fields in the treatment of cervical osteoarthritis: a randomized, double-blind, sham-controlled trial. Rheumatol Int 2006; 26: $320-4$.

26. Lee PB, Kim YC, Lim YJ, Lee CJ, Choi SS, Park SH et al. Efficacy of pulsed electromagnetic therapy for chronic lower back pain: a randomized, double-blind, placebo-controlled study. J Int Med Res 2006; 34: $160-7$.

27. Thuile Ch, Walzl M. Evaluation of electromagnetic fields in the treatment of pain in patients with lumbar radiculopathy or the whiplash syndrome. NeuroRehabilitation 2002; 17: 63-7.

28. Trock DH, Bollet AJ, Markoll R. The effect of pulsed electromagnetic fields in the treatment of osteoarthritis of the knee and cervical spine: report of randomized, double blind, placebo controlled trials. J Rheumatol 1994; 21: 1903-11.

29. Jacobson JI, Gorman R, Yamanashi WS, Saxena BB, Clayton L. Lowamplitude, extremely low frequency magnetic fields for the treatment of osteoarthritic knees: a double-blind clinical study. Altern Ther Health Med 2001; 7: 54-64. 